\title{
Allmänhetens syn på våldsbejakande extremism: En balans mellan sociala, ekonomiska och polisiära åtgärder ${ }^{1}$
}

Lars Korsell, docent i kriminologi, gästforskare Högskolan Dalarna; Tomas Axelson, docent i religionssociologi, verksamhetsledare Interkulturellt utvecklingscentrum Dalarna, Högskolan Dalarna \& Jonas Stier, professor i socialt arbete, Mälardalens högskola

\begin{abstract}
The so-called Swedish model of trust is characterised by strong public support for the idea of an individual-based and extensive welfare state, well-developed state individualism, high levels of social trust, widespread appreciation of the judiciary, openness, tolerance, and a free and independent press. Today, Swedish society faces several challenges. Will the Swedish model of trust be eroded or is it relatively resilient to stress?

A Novus survey from 2019 found that a total of 74 percent of the Swedish population were very or quite worried about Islamic extremism, 66 percent very or quite worried about right-wing extremism and 46 percent very or quite worried about left-wing extremism. Other surveys show that the public is also concerned about the deterioration of the welfare state, social gaps, the increased number of refugees to Sweden and xenophobia. Moreover, the Novus survey shows that 65 percent believe that violence-promoting extremism will increase in Sweden in the coming ten-year period. 22 percent indicate that they have become suspicious of people they have encountered in everyday situations and 15 percent have avoided large crowds, e.g. shopping malls, pedestrian areas and subways.

When asked which measures are good for increasing security in society, common answers were to reduce social exclusion, increase camera surveillance in public places and provide more information on democratic principles and values. These answers indicate that Swedish public opinion has a relatively balanced view of public measures against violent extremism, which is consistent with
\end{abstract}

1. Title in English: The public view of violent extremism: a balance between social, economic and police measures 
the Swedish model of trust. In general, the public does not propose the implementation of overly excessive measures against violent extremism. However, given continued public concern over the development of violent extremism, the long term stability of the Swedish model of trust remains in question.

\section{Keywords}

Violent extremism, Sweden, attitudes, trust, worry

Våldsbejakande extremism, Sverige, attityder, tillit, oro

\section{Inledning}

Attitydundersökningar och forskningsrapporter visar att den svenska allmänheten under det senaste decenniet uttryckt en stigande oro för »terrorism《 (Martinsson och Andersson 2018, s. 21). Under en femårsperiod hade den procentuella andelen svenskar som uttryckte mycket stor oro för terrorism ökat från ca 30 procent 2012 till att uttryckas av 60 procent av befolkningen 2017. Också mycket stor oro för politisk extremism har visat en stigande kurva utslaget på flera år. Andra SOM-undersökningar inriktade på attityder om våld och demokrati, visar att mer än 95 procent av svenska folket tar avstånd från tanken att använda våld för att påverka det svenska samhället (Tippe 2018, s. 16). Ideologiskt motiverad våldsutövning har blivit en alltmer uppenbar källa till friktion i samhället och forskningsfältet har både internationellt och i Sverige vuxit snabbt och blivit mycket omfattande. Redan för trettio år sedan publicerade ledande sociologer som Anthony Giddens (1990) och Ulrich Beck (1992) studier som pekade på problem i det senmoderna samhället med underliggande osäkerhets- och riskfaktorer. Idag söker kriminologer, sociologer och statsvetare förstå vilka processer i samtiden som leder till minskad tillit till samhället och ökad intolerans och extremism (Norris och Inglehart 2019, Eatwell och Goodwin 2018, Björgo 2013). Hur ser då svenska folket explicit på våldsbejakande extremism och vilka idéer formuleras av allmänheten om bästa sättet att motverka extremism i det svenska samhället?

På uppdrag av Länsstyrelsen i Dalarnas Län och Högskolan Dalarna genomförde därför undersökningsföretaget Novus i september 2019 en intervjuundersökning om allmänhetens syn på våldsbejakande extremism (Novus 2019). Intervjuundersökningen innehöll såväl fasta svarsalternativ som fritextssvar. I den här artikeln redovisas och diskuteras såväl det kvantitativa resultatet av undersökningen som de kvalitativa fritextsvaren. Samtidigt försöker vi sätta in framför allt fritextsvaren i ett större samtidstolkande sammanhang. Referenspunkten är något som vi kallar för den svenska tillitsmodellen. Med stöd av bland andra historikern Lars Trägårdh tolkas resultatet av undersökningen mot bakgrund av en kontext av 
hög uppslutning bakom idén om det individbaserade och ambitiösa välfärdssamhället (Trägårdh 2013). Med det menar vi några dominerande drag i det svenska samhället som en utvecklad statsindividualism (Berggren och Trägårdh 2014), det lutherska arvet av plikter, skyldigheter och individuell autonomi (Claesson 2019), hög generell tillit (Rothstein och Holmberg 2019, Nordiska rådet 2017), kombinerat med en avvaktande hållning gentemot en separatistisk och sociocentrisk religionsutövning (Axelson och Stier, in print, Axelson et al. 2018). Till bilden av den svenska tillitsmodellen av samhällstillit kan också läggas en hög skattning av rättsväsendet, öppenhet, tolerans, information, oberoende journalistik, rättskänsla och ömsesidiga solidaritetsprinciper, enligt devisen 'gör din plikt och kräv din rätt'.

Svaren i denna undersökning diskuteras även i jämförelse med senare års SOM-undersökningar och andra attitydundersökningar. Därmed ges möjlighet att diskutera Novus-undersökningens resultat i ljuset av långsiktiga trender kring oro för politisk extremism, terrorism och organiserad brottslighet samt mot bakgrund av hur det förebyggande arbetet mot våldsbejakande extremism har formulerats.

\section{Undersökningen - allmänhetens relation till våldsbejakande extremism}

Spontana associationer om våldsbejakande extremism

Undersökningen genomfördes via webbintervjuer med Novus »Sverigepanel«, där 1054 personer i åldern 18-79 år tillfrågades. Deltagarfrekvensen var 57 procent, vilket får betraktas som en relativt hög siffra i sammanhanget. Novus genomför sina webbintervjuer med en slumpmässigt rekryterad och riksrepresentativ panel. ${ }^{2}$ Bedömningen är därför att bortfallet inte påverkar eller snedvrider resultatet utan det är åsiktsmässigt representativ för den svenska allmänhetens inställning till och uppfattning om extremism. Förutom webintervjuernas frågor med fasta svarsalternativ fanns en öppen fråga om vad respondenterna associerar med våldsbejakande extremism. Med detta upplägg gav undersökningen såväl kvantitativa som kvalitativa data, vilka redovisas och diskuteras i denna artikel.

Sammanlagt 219 personer (av 601 svarande) har utnyttjat möjligheten att formulera ett fritextsvar. I flesta fall går svaren i riktning mot islamistisk extremism. Det uttrycks i svar som »IS«, »IS-krigare« och »radikala muslimer«, m.m. Underlaget i tabellen nedan är begränsat till dem som nyttjat möjligheten att svara

2. För mer information om upplägg, signifikans och felmarginal, se länk till Novusundersökningen. 
och är därmed inte representativt för hela populationen. Men tendenser kan identifieras enligt följande kategorier.

\section{Tabell 1. Översikt av frivilliga svar gällande tankar om våldsbejakande extremism}

Svar på öppen fråga: Vad är det första du kommer att tänka på när du hör uttrycket 'våldsbejakande extremism'?

\begin{tabular}{lc}
\hline Kategorier av svar & Antal \\
\hline Islamistisk extremism: & \\
IS, ISIS, Is-krigare, salafism, talibaner, radikala muslimer, islamister, muslimer, & \\
islam, muslimska friskolor m.m. & 84 \\
Högerextremism: & 15 \\
NMR, vit makt, nazister, rasism, högerextremister & \\
SD plus högernationalism: & 10 \\
Sverigedemokraterna, högersvans, m.m. & \\
Vänsterextremism & 11 \\
AFA, kommunism, autonoma, Baader-Meinhof, m.m. & 15 \\
Svar som inbegriper två eller flera av ovanstående miljöer & \\
\hline
\end{tabular}

Ett större antal på 84 enskilda svarande har formulerat fritextsvar som i hög grad associerar till olika former av islamism och islam.

Svaren förmodar vi speglar den uppmärksamhet som riktats mot förhållandevis aktuella händelser i Syrien och Irak. När enkäten gjordes hade frågan om återvändare från kriget i flera år fått stor uppmärksamhet. Flera terrordåd runt om i Europa för också tanken till islamistisk extremism. Någon har tagit intryck av samtidsdebatten och skrivit »islamiska friskolor« och syftar förmodligen på skolor som misstänks för att understödja extremism. Flera har angett »islam« och »islamister«. Det kan tolkas som att många omfattar en syn på problemet med våldsbejakande islamistisk extremism som att det snarare ligger i religionen som sådan. Någon enstaka har svarat »salafism《, vilket visar kunskap om en viss radikal riktning inom islam (jmf. Ranstorp 2018). Dessa islamfientliga tolkningar förstärks i svaren om det bästa sättet för samhället att motverka extremism. Ett förslag är att införa stränga regler för religiösa friskolor. Här ser vi en glidning i svaren i ett avståndstagande riktat både mot »mainstream « islam och varianter av radikalare tolkningstraditioner. 
Efter ett större antal som associerar till islamistisk extremism ser vi ett visst antal som spontant associerar till »vit makt«, »nazister«, högerextremister« och i några fall specificerat till »Nordiska motståndsrörelsen« $\left(\mathrm{NMR}^{3}\right)$. Det kan förklaras med att den högerextremistiska vit makt-rörelsen i hög grad varit synlig under senare år, inte minst genom större demonstrationer (Korsell et al. 2020). Tar man med svar som också inkluderar »Sverigedemokraterna med svans« adderas ytterligare ett antal individer som ger svar i högerriktning.

Trots att den vänsterinriktade autonoma rörelsen på senare tid inte fått särskild mycket uppmärksamhet är det ändå ett antal som efter högerextremism pekar ut »vänsteraktivister«, »autonoma vänsterrörelser « »kommunism《 och anger särskilt $»$ Antifascistisk aktion« (AFA).

Räknar man ihop de öppna fritextsvaren är det tydligt att det hos dem som spontant skrivit sådana svar synes det ha funnits en vilja att särskilt peka ut islamistisk extremism. I undersökningsdelen med fasta svarsalternativ var det relativt sätt fler som också beaktat höger- och vänsterextremism, något som vi återkommer till.

Är allmänheten orolig?

Hur ser då allmänhetens eventuella oro ut för olika typer av extremism och i vilken grad är man orolig.

Tabell 2. Grad av oro för olika typer av extremism i Sverige?

Svar på fråga: Skulle du säga att du är orolig eller inte orolig, för följande typer av extremism i Sverige?

\begin{tabular}{lccccc}
\hline & $\begin{array}{c}\text { Mkt } \\
\text { orolig }\end{array}$ & $\begin{array}{c}\text { Ganska } \\
\text { orolig }\end{array}$ & $\begin{array}{c}\text { Inte särsk } \\
\text { orolig }\end{array}$ & $\begin{array}{c}\text { Inte alls } \\
\text { orolig }\end{array}$ & Vet ej \\
\hline $\begin{array}{l}\text { Islamistisk extremism } \\
\text { (militant jihadism) }\end{array}$ & $38 \%$ & $36 \%$ & $22 \%$ & $3 \%$ & $1 \%$ \\
$\begin{array}{l}\text { Högerextremism } \\
\text { (nazism, vit makt-grupper) }\end{array}$ & $27 \%$ & $39 \%$ & $26 \%$ & $6 \%$ & $2 \%$ \\
$\begin{array}{l}\text { Vänsterextremism } \\
\text { (autonoma vänstergrupper, } \\
\text { militanta djurrättsaktivister) }\end{array}$ & $16 \%$ & $30 \%$ & $39 \%$ & $14 \%$ & $1 \%$ \\
\hline
\end{tabular}

3. NMR (Nordiska motståndsrörelsen, en nationalsocialistisk rörelse aktiv i Norden). 
I undersökningen kan man alltså se att sammanlagt 74 procent $(38+36 \%)$ var mycket eller ganska oroliga för islamistisk extremism, 66 procent mycket eller ganska oroliga för högerextremism och 46 procent mycket eller ganska oroliga för vänsterextremism.

Allmänheten verkar på det stora hela ha en god inblick i vad som döljer sig bakom begreppet våldsbejakande extremism. Sett till de tre huvudinriktningarna är svaren förståeliga eftersom islamistisk extremism har fått störst uppmärksamhet och av Säkerhetspolisen återkommande pekats ut som det största problemet följt av höger- och vänsterextremism. Av de tillfrågade var 38 procent mycket oroliga för islamistisk extremism, 27 procent högerextremism och 16 procent avstava

vänsterextremism. På frågan om hur många anhängare våldsbejakande extremism har i Sverige, låg svaret på mellan 501-5000 personer, med ett medianvärde på 3000. Säkerhetspolisen (2017) bedömer att det totala antalet är just 3000 personer.

Allmänheten får därmed anses vara välinformerad om antalet extremister. Samtidigt får rangordningen av hotet från olika extremistschatteringar och graderingen av hotet anses vara kunskapsbaserat. Med tanke på medierapporteringen av terrorattentat med islamistiska förtecken på senare år (Axelson et al. 2018, s 36) kunde en oreflekterad uppfattning $i$ ännu högre grad ha lyft fram hotet från islamistisk extremism och tonat ner vit makt-miljön (högerextremism) och den autonoma miljön (vänsterextremism). I någon mån belyser andelen fritextsvar en sådan »magkänsla« hos allmänheten.

\section{Drottninggatan 7 april 2017}

Terrordådet på Drottninggatan den 7 april 2017 har satt djupa spår i allmänhetens medvetande. Många har angett Drottninggatan som fritextsvar på frågan om de själva eller någon anhörig har drabbats. Så många som 3 procent av de tillfrågade mellan 18 och 79 år anger att de själva drabbats av ett terrordåd, dvs. motsvarande ca 200000 svenskar. Räknar vi också in de som känner någon som drabbats så tillkommer ytterligare 14 procent, vilket innebär att betydligt fler än en miljon i Sverige antingen själva eller någon de känner har drabbats av terrordåd. Det kan antas att terrordådet på Drottninggatan den 7 april 2017 har satt djupa spår i allmänhetens medvetande. Många har angett just Drottninggatan som fritextsvar på frågan om de själva eller någon anhörig har drabbats. Siffrorna är väl höga och ett rimligt antagande är att en hel del svarande har besvarat frågan som att det handlar om att dådet i hög grad har påverkat dem, snarare än person- 
ligen drabbat dem. Det ligger i linje med den dömde terroristen Rakhmat Akilovs försvarare, advokat Johan Erikssons, påstående att »hela Sverige var målsägande « (Eriksson 2020).

Det är ändå påfallande hur många av de svarande som har en närmare erfarenhet av dådet genom att känna någon som var där: »Min vän var på Drottninggatan 7 april«, »en vän bevittnade terrordådet«, »min kusin har varit med i dådet«, »kompis dotter ...«, »en dotter med familj bor i huset ...«, »en väns syster var på Drottninggatan och såg ... « och »anhörig var på Drottninggatan«.

Några av de svarande var på plats, i närheten eller påverkades av dådet: »ögonvittne«, »närvarande vid Drottninggatan när lastbilen ...«, »var i centrala Stockholm vid attacken på Drottninggatan«, »var i Hötorgshallen vid terrordådet på Drottninggatan«, »var vid Drottninggatan«, »arbetade i närheten av Drottninggatan« eller »fastnade« i Stockholm eller hade »svårt att komma hem« till följd av att de allmänna kommunikationerna låg nere. En person hade till och med bevittnat »bägge dåden på Drottninggatan«, det vill säga även attentatsförsöket nära Drottninggatan den 11 december 2010.

Ur flera synvinklar var terrordådet en exceptionell händelse, inte minst för det närmast unika med ett terrordåd med flera dödsfall på svensk mark. Dessutom ägde dådet rum på en gågata $\mathrm{i}$ centrala Stockholm där en lastbil användes som dödsbringande redskap.

Mot den bakgrunden kan det framstå som obefogat att hänvisa till den svenska tillitsmodellen, men av fritextsvaren att döma är det flera svarande som i extremistsammanhang på ett tankeväckande sätt också associerar och hänvisar till mindre allvarlig brottslighet. Ganska många har erfarenhet av »oroliga demonstrationer« eller manifestationer som har »urartat«, lett till »våldsamt upplopp« med högerextremister eller där höger- och vänsterextremister drabbats samman. En person hade sett NMR demonstrera och karaktäriserade det som »extremt obehaglig«. Ett par personer hade »Göteborgskravallerna« år 2001 i färskt minne. Det var då den autonoma vänstern under flera dagar drabbade samman med ordningsmakten och vandaliserade paradgatan Kungsportsavenyn (SOU 2002:122). Några få svarande har själva förutom vid Göteborgskravallerna och Drottninggatan, drabbats av eller varit nära extremistiskt våld.

Att även höger- och vänsterextremisters våldsutövning har beaktats kan möjligtvis bero på är att de svarande refererat till egna erfarenheter och vad de själva bevittnat på nära håll. Samtidigt kan det vara ett uttryck för att extremisters synliga, kaosartade och besinningslösa våldsanvändning uppfattas som skrämmande och främmande i förhållande till den lag och ordning som kännetecknar den svenska tillitsmodellen. Även om det är stora gradskillnader i fråga om våldsan- 
vändning - från dödligt våld som rubriceras som terroristbrott till sammandrabbningar vid demonstrationer som betecknas som våldsamt upplopp - uppfattas det som äger rum som i hög grad avvikande för att inte säga väsensskilt från det som den svenska tillitsmodellen uppfattas stå för.

Ytterligare en tolkning är att allmänheten kan anses göra en riskbedömning. Extremisters våldsanvändning i samband med upplopp kan när som helst förändras till något mycket allvarligare: igår våldsam motdemonstrant, i morgon attentatsperson. Denna upplevda risk och oberäknelighet kan vara förklaringen till varför allmänheten framför allt lyfte fram vit makt-miljön efter islamistisk extremism. Enligt norska forskare har Sverige sett till folkmängden under de senaste tjugofem åren drabbats av flest gärningar av dödligt våld med högerextremistiska förtecken i Västeuropa (Due Enstad och Aasland Ravndal 2015). En gärning har då definierats som när en eller flera personer dödats vid ett och samma dåd, inte antalet offer. Den senaste gärningen av det slaget kan dateras till 2016 när flera personer miste livet vid Kronans skola i Trollhättan.

\section{Kriminella gäng}

De kanske mest oväntade och på flera sätt intressanta svaren gällde »kriminella gäng «, »skjutningar«, »gängkrig« och »kriminella personer oavsett religion, etnicitet«. En person har bevittnat en »skottlossning på en pizzeria« och en annan har angett »knivattack«. Andra har varit åskådare till »gängsammandrabbning i Stockholm«, »bilbränder« eller påverkats av en »sprängning i närheten av lägenheten«.

Det är tydligt att raden av skjutningar och sprängningar av ett tiotal fritextsvarande uppfattas som ett uttryck för våldsbejakande extremism, förmodligen i betydelsen terrorism. I den allmänna debatten har liknande åsikter förts fram, att det väpnade kriminella våldet på svenska gator och torg fått effekter som liknar terrorism (Agrell 2019).

Fritextsvararnas analys att likställa våldsbejakande extremism och terrorism med raden av skjutningar och sprängningar på offentlig plats anknyter till en debatt om sambandet (»nexus«) mellan organiserad brottslighet och terrorism (Fijnaut et al. kommande, Korsell kommande). I en uppmärksammad artikel argumenterade Makarenko (2004) för att de båda, från varande separerade fenomenen organiserad brottslighet och terrorism, började visa operativa och organisatoriska likheter. I en skala beskrev han hur organiserad brottslighet respektive terrorism från varsitt håll närmade sig varandra genom allianser, användning av den andres taktik för att $\mathrm{i}$ slutändan, när integrationen gått tillräckligt långt, smälta samman (»the black hole syndrome«). 
På motsvarande sätt som med terror kan de kriminellas vilja att på ett utmanande sätt demonstrera sitt våldskapital uppfattas som ett i hög grad främmande element i det svenska samhället och därmed för den svenska tillitsmodellen. Hänvisningen till terror gör sig förmodligen särskilt starkt gällande när tredje man riskerar att skadas eller dö, det vill säga personer som råkar befinna sig på fel plats vid fel tidpunkt. Våldet framstår som delvis obegripligt, slumpmässigt och därför särskilt skrämmande. Ett rekvisit i lagstiftningen om terroristbrott är just att det ingjuter allvarlig fruktan hos befolkningen (SOU 2019:49).

\section{Höger- och vänsterextremism}

Av svaren att döma finns en skillnad mellan å ena sidan islamistisk extremism och å andra sidan höger- och vänsterextremism. Det är tydligt att i fråga om islamistisk extremism är allmänheten visserligen oroad för attentat, men det man tycks vända sig emot är de religiösa värderingarna som manifesteras i islamistisk extremism, som uppfattas vara mer stötande för det svenska samhället än de politiskt ideologiska värderingarna. Uppfattat som en underliggande religionsfientlighet går detta att se i andra attitydundersökningar under senare år där en så stor majoritet som 75 procent av befolkningen i Skandinavien ser religion som ett konfliktgenererande fenomen i världen (Lövheim et al. 2018). I särskilt hög utsträckning betraktas islam med misstänksamhet och som ett potentiellt hot mot svensk, norsk eller dansk kultur (Lövheim et al. 2018, s. 40). Närmare 40 procent i Sverige och omkring 50 procent i Norge respektive Danmark uttryckte en sådan hållning.

När det gäller höger- och vänsterextremism går svaren att tolka som att visserligen uppfattas våldsanvändningen på svenska gator och torg som skrämmande, men extremismens ideologiska hemvist är ändå bekant på ett annat sätt än för islamistisk extremism. Människor har också levt, upplevt och har historiska kunskaper om höger- och vänsterextremism, och varken Nazityskland eller Sovjetunionen är långt borta. Även om dessa jämförelser inte alltid är korrekta och relevanta, särskilt inte för vänstersidan, är det ändå något konkret för allmänheten att förhålla sig till.

På en punkt indikerar dock enkätsvaren ett djupgående motstånd mot högerresp. vänsterextremism som i någon mån påminner om aversionerna mot islamistisk extremism. För högerextremism gäller det den idag politiskt laddade synen på invandring. När fritextsvar sätter likhetstecken mellan högerextremism och Sverigedemokraterna får det anses vara ett ställningstagande för den del av svenska tillitsmodellen som betonar öppenhet och tolerans. 
När fritextsvaren likställer vänsterextremism med exempelvis Vänsterpartiet kan även det ses som ett tydligt ideologiskt uttryck för att inte avvika för långt ut mot kanterna. Med andra ord skulle det vara ett uttryck för den svenska tillitsmodellens konsensustänkande där merparten befinner sig politiskt i en bred mittfåra i landet lagom - »mellanmjölkens land « - något som i dag utmanas när Sverigedemokraterna och Vänsterpartiet tillsammans har börjat representera nästan en tredjedel av valmanskåren.

\section{Invandring som förklaring}

Även om vi menar att den svenska tillitsmodellen bygger på tolerans är den inte entydig i fråga om invandring. Åtskilliga fritextsvar ser ett problem med för mycket invandring. Det finns svarande som menar att det är invandringen som är problemet med våldsbejakande extremism. Särskilt framgår det av frågan om vad de fritextsvarande tror är det bästa sättet för samhället att motverka extremism. Där finns svar som »stäng våra gränser för invandring «, »mindre invandring «, »tillfälligt strypa invandringen (ej arbetskraftsinvandring)«, »stänga gränserna« och »inte låta dom komma in i Sverige«.

Som nyss nämnts har några svarande sammankopplat extremism med raden av skjutningar och pågående gängkrig. Bortsett från att denna våldsutövning på öppen gata anses som främmande för ett välfungerande land som Sverige, kan man se en koppling till en oro för invandring och islamistisk extremism i betydelsen att både skjutningar och islamistisk extremism uppfattas ha att göra med invandring i de öppna svaren. Invandring ses som en förklaringsfaktor för en person som bevittnat »rån på öppen gata« eller en annan som angett »våldtäkt på grund av att hon var svensk «.

Ser man till undersökningens representativa utfall väger betoningen på invandring som förklaringsfaktor betydligt mindre. Det är 66 procent som är mycket eller ganska oroliga för högerextremism och 46 procent som är mycket eller ganska oroliga för vänsterextremism jämfört med 74 procent för islamistisk extremism. Framför allt förknippas inte högerextremism med invandring och invandrare.

Detta resultat överensstämmer väl med svaren på frågan om $d u$ är orolig eller inte orolig för att du själv eller någon av dina anhöriga ska drabbas av våldsamt upplopp eller terrordåd. Det var 36 procent som svarade att de var mycket eller ganska oroliga för terrordåd och 28 procent för våldsamt upplopp. Ett rimligt antagande är att allmänheten till stor del förknippat terrordåd med islamistisk extremism och våldsamt upplopp med höger- och vänsterextremism. 
Undersökningens resultat i öppna fritextsvar ger en tankeväckande bild av hur allmänheten hösten 2019 associerar och tänker kring fenomenet våldsbejakande extremism. De riktigt intressanta svaren levererades dock på de framåtsyftande frågarna om hur Sverige bäst arbetar för att stärka säkerheten i samhället mot riskerna med extremistiskt våld.

\section{Motverka extremism - en balans av många olika åtgärder}

Undersökningen visar att allmänheten många gånger ser komplexiteten i hur man bäst motverkar extremism. På frågan om bästa sättet för samhället att öka säkerheten och minska hotet från extremistiskt våld framträder ett intressant svarsmönster som balanserar sociala, polisiära, normativa och ekonomiska åtgärder enligt tabellen nedan.

\section{Tabell 3. Synpunkt på åtgärder för att öka samhällets säkerhet?}

Svar på fråga: Hur bra eller dåligt tycker du att följande åtgärder är för att öka säkerheten i samhället?

\begin{tabular}{|c|c|c|c|c|c|c|}
\hline Åtgärd & $\begin{array}{c}\text { Mycket } \\
\text { bra }\end{array}$ & $\begin{array}{c}\text { Ganska } \\
\text { bra }\end{array}$ & $\begin{array}{l}\text { Varken } \\
\text { eller }\end{array}$ & $\begin{array}{l}\text { Ganska } \\
\text { dåligt }\end{array}$ & $\begin{array}{c}\text { Mkt } \\
\text { dåligt }\end{array}$ & Vet ej \\
\hline Minska utanförskap i samhället & $60 \%$ & $25 \%$ & $9 \%$ & $2 \%$ & $2 \%$ & $2 \%$ \\
\hline $\begin{array}{l}\text { Ökad kameraövervakning på offent- } \\
\text { liga platser }\end{array}$ & $52 \%$ & $28 \%$ & $11 \%$ & $5 \%$ & $3 \%$ & $1 \%$ \\
\hline $\begin{array}{l}\text { Mer information om demokratiska } \\
\text { principer och värderingar }\end{array}$ & $53 \%$ & $26 \%$ & $13 \%$ & $4 \%$ & $2 \%$ & $2 \%$ \\
\hline Ökade möjligheter till utvisning & $56 \%$ & $20 \%$ & $12 \%$ & $5 \%$ & $4 \%$ & $3 \%$ \\
\hline Minska ojämlikhet i samhället & $49 \%$ & $24 \%$ & $17 \%$ & $5 \%$ & $3 \%$ & $3 \%$ \\
\hline Strängare straff & $48 \%$ & $23 \%$ & $15 \%$ & $8 \%$ & $4 \%$ & $2 \%$ \\
\hline Frihetsberöva »riskpersoner« & $36 \%$ & $25 \%$ & $15 \%$ & $11 \%$ & $7 \%$ & $6 \%$ \\
\hline $\begin{array}{l}\text { Ökade möjligheter för myndigheter att } \\
\text { avlyssna hem, telefoner, mm. }\end{array}$ & $27 \%$ & $28 \%$ & $15 \%$ & $13 \%$ & $15 \%$ & $2 \%$ \\
\hline Minskad invandring & $35 \%$ & $16 \%$ & $23 \%$ & $10 \%$ & $12 \%$ & $3 \%$ \\
\hline $\begin{array}{l}\text { Ökade möjligheter för myndigheter att } \\
\text { kontrollera vad folk gör på internet }\end{array}$ & $19 \%$ & $24 \%$ & $19 \%$ & $20 \%$ & $14 \%$ & $3 \%$ \\
\hline $\begin{array}{l}\text { Ökade möjligheter för myndigheter att } \\
\text { läsa folks mail }\end{array}$ & $12 \%$ & $20 \%$ & $21 \%$ & $22 \%$ & $22 \%$ & $3 \%$ \\
\hline $\begin{array}{l}\text { Ökade möjligheter för myndigheter att } \\
\text { registrera folks åsikter }\end{array}$ & $10 \%$ & $20 \%$ & $19 \%$ & $20 \%$ & $27 \%$ & $4 \%$ \\
\hline
\end{tabular}


Följande huvudriktningar framträder i enkät- och fritextsvar som vi vill kommentera och diskutera.

\section{Minskade klyftor och bättre framtidsutsikter}

Minskat utanförskap i samhället anser 60 procent av de tillfrågade vara en mycket bra åtgärd för att öka säkerheten i samhället. I de öppna fritextsvaren beskrivs det som exempelvis »minskade klyftor« och »minskade klassklyftor«. Det var 49 procent som ansåg att minskad ojämlikhet som en mycket bra åtgärd. En aspekt av minskade klyftor är att satsa mycket på barn och ungdomar i »utsatta miljöer « och »förebyggande arbete mot utanförskap hos barn och unga«. »Fungerande skolor« och »värnplikt« nämns i fritextsvaren. Värnplikt kan tolkas som att det bidrar till integration samtidigt som det har en fostrande effekt.

\section{Öppenhet och utbildning}

Mer information om demokratiska principer och värderingar anser 53 procent är en mycket bra åtgärd för att öka säkerheten i samhället. Åtskilliga svarande med fritextsvar tror att »öppenhet«, ett »orubbligt öppet« samhälle, är viktigt, sannolikt för att skapa ett tolerant samhälle med mindre konflikter. Alla ska ha samma »värdegrund«. »Utbildning och information«, »kunskap« bör leda till förmåga att stå emot propaganda. Någon föreslår upplysning om extremismens mörka sidor. »Seriös nyhetsförmedling och etablerade medier« ses som ett värn mot extremism och förmodligen mot konspirationsteorier. Utbildning är viktigt, men skolorna bör dock vara »sekulära«, vilket riktar sig mot religiösa friskolor. En slår ett slag för lärarnas kompetens och förmåga att uppfostra »demokratiska medborgare«. »Inkludera, skapa humanitära och empatiska medborgare« föreslår en svarande och en annan "preventivt, få människor att känna sig som en del av samhället«. »Framtidshopp, bostad och utbildning « föreslås.

Det är möjligt att det i grund och botten är svårt att skilja mellan å ena sidan öppenhet och utbildning och å andra sidan minskade klyftor, men att de som svarat gör olika betoningar. En svarande menar att extremisterna ska få möjlighet att ventilera sina uppfattningar för då får alla höra hur »konstiga värderingar och åsikter de har ... Tvingar vi in dom i skuggan frodas dom«.

\section{Motverka invandring}

Som tidigare har nämnts är det tydligt att en grupp svarande ser invandring som en källa till extremism, men detta svar hamnar tämligen långt ner på listan - på nionde plats - när svaren från den representativa delen av intervjuundersökningen tolkas. Det är 35 procent som anser att minskad invandring är en mycket bra åt- 
gärd för att öka säkerheten i samhället. I fritextsvaren föreslås också minskad invandring, men även »återvandring «. En mindre radikal uppfattning som numera får anses ha brett stöd i riksdagen är att ta in så många invandrare som man klarar av att »anpassa« i samhället. Asylsökande som har fått avslag föreslår någon bli avvisade »omedelbart«. Andra fritextsvar är att Sverige under »ett tag« bör stänga sina gränser och dessutom utvisa vid »minsta lilla brott«. Nära frågor om invandring ligger förslag i fritextsvaren om »hårdare gränskontroll«. Likaså att ha bättre kontroll över vilka som vistas i landet. Detta är uppfattningar som ligger nära det polisiärt förebyggande arbetet.

\section{Polisiärt förebyggande arbete}

Det är tydligt att intryck har tagits av den allmänna debatten om kameraövervakning. Ökad kameraövervakning anser 52 procent vara en mycket bra åtgärd för att öka säkerheten i samhället. Det får anses vara en överraskande hög siffra eftersom man kan anta att extremister iakttar försiktighet vid planerade våldsdåd för att undgå att identifieras. I fritextsvaren föreslås polisiär »övervakning av misstänkta« och »punktvis övervakning«. »IS-krigare« föreslås inte få återvända hem. Antingen ska det förebygga brott i Sverige eller möjligen ses som ett slags bestraffning att inte få återvända till Sverige i betydelsen fristat och välfärdsland.

Det är 19 procent som ser myndigheternas ökade möjligheter att kontrollera vad medborgare gör på internet som en mycket bra åtgärd, 12 procent att läsa folks mail och 27 procent att avlyssna hem, telefoner m.m. Ökade möjligheter att registrera medborgarnas åsikter anser 10 procent vara en mycket bra åtgärd. Inte mindre än 36 procent ser möjligheten att frihetsberöva »riskpersoner« som en mycket bra åtgärd.

Med andra ord anses extremism vara ett så allvarligt hot att åtskilliga svarande menar att integritetskänsliga åtgärder ska tillåtas för att förebygga brott. Sannolikt uppfattas dock inte kameraövervakning som särskilt integritetskänsligt längre med tanke på att det blivit allt vanligare och knappast har motiverats för att motverka extremism. Däremot anses säkert de andra formerna av övervakning som väsentligt mer integritetskänsliga. Ett ytterligare perspektiv vid sidan av att samhället måste tåla ingripande åtgärder mot en så pass allvarlig brottslighet kan vara att ideologiskt utövande av politiskt våld uppfattas komma från en liten men potentiellt mycket farlig grupp med kapacitet att utgöra ett allvarligt hot mot det öppna samhället enligt den svenska tillitsmodellen. Det skulle innebära att de integritetskänsliga inslagen skulle beröra enbart en marginell grupp i samhället och därmed inte påverka gemene man. 


\section{Hårdare tag}

»Mer frihet för polisen, övervakningskameror och inget daltande med fritidsgårdar« föreslår en svarande och andra vill ha »straff«, »hårdare straff«, »sätta hårt mot hårt« och »utvisning«. Med utvisning måste avses islamistiska extremister som inte är svenska medborgare. Ett förslag är att sluta »dalta med IS-återvändare« och det är antagligen straff som avses.

En person föreslår ett bredare polisiärt arbete med nolltolerans och hänvisar till New York. Tanken är förmodligen att små brott kan leda till stora brott. Därför är det effektivt att även motverka mindre allvarlig brottslighet. En person föreslår att extremistiska rörelser ska förbjudas och nämner särskilt NMR. Förslaget följer en debatt där bland annat Finland förbjudit sin egen motsvarighet. En lite ovanlig kombination är att krafttag ska riktas mot både islamistisk extremism och vänsterextremism.

Några svarande vill satsa både på förebyggande åtgärder och en »fungerande rättsprocess« eller »utbildning, skola och bättre resurser till polisen«. »Kunskap och poliser« illustrerar samma tema liksom »information, information, information. Sen en hel del övervakning.«

\section{Rädsla och oro inför framtiden}

En fråga i enkäten syftade på med vilket framtidsperspektiv man betraktar utvecklingen i samhället gällande våldsbejakande extremism.

\section{Figur 1. Syn på den fortsatta utvecklingen gällande våldsbejakande extremism}

Svar på fråga: Om du ser framåt 10 år, hur tror du våldsbejakande extremism utvecklats $i$ Sverige?

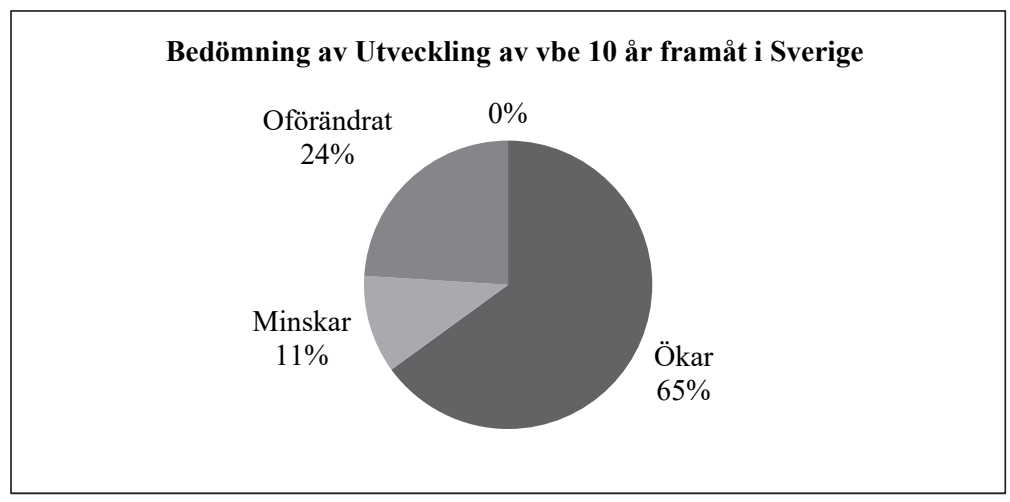


Inte mindre än 65 procent tror att våldsbejakande extremism kommer att öka i Sverige om man ser tio år framåt i tiden. Enbart 11 procent tror på en minskning. Allmänheten uttrycker således en mörk bild vad gäller samhällets förmåga att vända utvecklingen.

\section{Påverkan på vardagen}

Ett annat svar att reflektera djupare över är den påverkan i vardagslivet som människor uppger på grund av rädsla för våldsamt upplopp och terrordåd. I enkäten ställde vi frågor huruvida allmänheten uppfattar att man ändrat sitt beteende i något avseende.

\section{Tabell 4. Påverkan på vardagen}

Svar på fråga: Har du under de senaste 12 månaderna gjort något av följande pga. rädsla för våldsamt upplopp eller terrordåd?

\begin{tabular}{lr}
\hline Förändrat beteendemönster & \\
\hline Blivit misstänksam mot människor jag mött i vardagssituationer & $22 \%$ \\
Undvikit stora folksamlingar (köpcenter, gågator, konserter, sportevenemang, t-bana, mm.) & $15 \%$ \\
Undvikit resor utomlands till platser som utsatts för terrordåd tidigare & $12 \%$ \\
Läst på och sökt upp information om terrorhot & $10 \%$ \\
Har inte gjort något av ovanstående & $56 \%$ \\
Annat & $3 \%$ \\
Vet ej & $3 \%$ \\
\hline
\end{tabular}

Nästan hälften har reagerat i något avseende på grund av rädsla för upplopp eller terrordåd. Det är 22 procent som anger att man blivit misstänksamma mot människor de mött i vardagssituationer och 15 procent har undvikit stora folksamlingar som köpcenter, gågator, konserter, sportevenemang och tunnelbana. Att mellan 10 procent och 20 procent av befolkningen uppger att man påverkats i vardagslivet i denna utsträckning stämmer till eftertanke och kan jämföras med tillitsforskningens rapporter på senare år. Sverige utmärker sig tillsammans med övriga nordiska länder och Nederländerna om att ha exceptionellt hög grad av tillit till människor i allmänhet, inklusive främlingar (Nordiska ministerrådet 2017). Denna attityd kallar Nordiska ministerrådets rapport för »det nordiska guldet« (2017). Hur denna tillit utvecklas i Sverige inom den närmaste framtiden är om- 
tvistat bland forskare, det vill säga huruvida den fortsätter att vara stabilt hög eller visar tendenser att vika nedåt.

SOM-undersökningarna under senare år ger indikationer på att en oro på en ny och högre nivå etablerat sig i samhället (Martinsson och Andersson 2019). År 2018 uppgav omkring 45 procent av den svenska befolkningen mycket stor oro för politisk extremism, terrorism och organiserad brottslighet, siffror som fluktuerat uppåt och nedåt men etablerat sig på en relativt hög nivå under de senaste fem åren (Martinsson och Andersson 2019, s 21). Enligt Brottsförebyggande rådets nationella trygghetsundersökning 2019 oroar sig drygt två femtedelar (43 procent) av befolkningen (16-84 år) i stor utsträckning över brottsligheten i samhället, vilket i princip är på samma nivå som 2018 (Brå 2019). Fram till och med 2011 minskade andelen som kände oro, och därefter skedde en ökning med årliga variationer som pågick fram till och med 2017 (Brå 2019). Till detta kan för året 2018 läggas en under samma femårsperiod etablerad mycket stor oro inför framtiden för försämrad välfärd (28 procent), sociala klyftor (31 procent) ökat antal flyktingar (36 procent) och främlingsfientlighet (42 procent) (Martinsson och Andersson 2019, s 22). Jämför vi med Novus-undersökningen från 2019 svarar 65 procent att de tror att våldsbejakande extremism kommer att öka i Sverige under den kommande tioårsperioden.

En fråga att reflektera vidare över är om denna iakttagna påverkan i vardagslivet kan tänkas kvarstå i framtida undersökningar. Vad händer på längre sikt utifrån att var femte svensk i denna undersökning anger att man blivit misstänksam mot människor man mött i vardagen, kan detta på sikt tänkas påverka den hittillsvarande attityden av hög tillit gällande människor i allmänhet? Eller kommer det att visa sig att en hög motståndskraft - resiliens - är en del av den svenska tillitsmodellen?

\section{Diskussion - tillit, oro och värnandet av demokrati}

Ett annat sätt att se det är att svaren efter viss avslipning mycket väl ligger i linje med samhället strategier mot våldsbejakande extremism och att stärka demokratin mot extremism. 
Figur 2. Samhällets åtgärder mot våldbejakande extremism

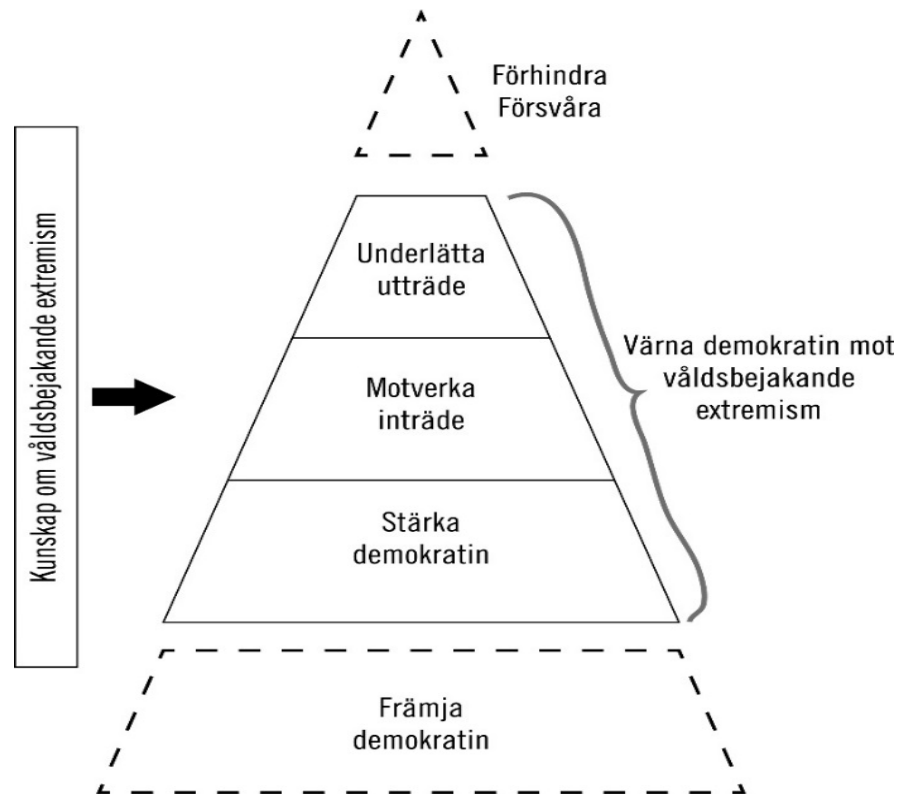

Preventionspyramid. (SOU 2016:92)

I basen på en tänkt åtgärdspyramid ligger demokrati, utbildning, välfärdssatsningar och andra breda och grundläggande åtgärder. Högre upp i pyramiden återfinns mer repressiva åtgärder. På vägen dit ligger ökad kameraövervakning eftersom det borde förutsätta även ingripanden och brottsutredning. Med andra ord åtgärder som ligger i linje med Novus-undersökningens resultat.

Det är åtgärder som riktar sig mot samtliga tre extremistriktningar och i olika stadier i en extremistisk inriktning. De grundläggande insatserna är tänkta att motverka att extremism över huvud taget får något fotfäste. När extremism leder till brottslighet har samhället åtgärder att sätta in. Om vi utgår från att det inte finns några standardlösningar mot extremism, får politiken inte bara anses avspegla allmänhetens uppfattningar utan även framstå som förnuftig: Demokrati, välfärd, öppenhet, information, tolerans och ett fungerande rättsväsende. Allt i enlighet med den svenska tillitsmodellen. 


\section{Slutsats}

I analysen av olika orosrapporter under senare år går att observera en långsamt ökad stor oro för försämrad välfärd, sociala klyftor, ökat antal flyktingar och främlingsfientlighet. Till det läggs en över tid ökad oro för politisk extremism, terrorism och organiserad brottslighet. Sammantaget visar dessa rapporter på att en fördjupad oro har etablerats hos allmänheten gällande samhällets förmåga att stävja fenomenet våldsbejakande extremism, som går stick i stäv med det svenska välfärdssamhällets idéer om tillit, stabilitet och rättssäkerhet.

Den genomförda Novus-undersökningen tecknar inte en överdrivet alarmistisk bild av en entydigt uttryckt etablerad pessimism, utan den ligger i linje med andra attitydundersökningar om svenska folkets förtroende för myndigheter. Till exempel SOM-rapporten från 2018 visar att människors tillit generellt till olika samhällsinstitutioner med uppgift att skydda samhället mot våld, som polis och rättsväsende, fortsatt ligger tämligen intakt på en relativt hög nivå över tid (Andersson et al. 2018, s, 23, se även Brå 2019). Dessa attityder ser vi som ett utslag för en existerande resiliens och motståndskraft mot större påfrestningar i samhället.

Novus-undersökningen ovan från 2019 förstärker den bilden och visar hur den svenska allmänheten har en balanserad syn på samhällets åtgärder mot våldsbejakande extremism, från breda normativa ansatser i samhällets bas till polisiära och rättsvårdande inslag i spetsen på preventionspyramiden. Överlag har allmänheten behållit fattningen och föreslår inte överilade åtgärder mot våldsbejakande extremism. Istället tror man att välfärd och minskade sociala klyftor är mycket bra åtgärder mot extremism: minska utanförskapet i samhället och mer information om demokratiska principer och värderingar samt kameraövervakning. Utbildning, normbildning, motverkande av segregation, inkludering och respekt för likhet inför lagen kopplas till rättsväsendets myndighetsutövning. I denna heta samtidsfråga finns således hos allmänheten en nyanserad blick som balanserar sociala, ekonomiska och polisiära åtgärder. Detta balanserade perspektiv hos allmänheten tolkar vi som ett resultat av den svenska tillitsmodellen.

Samtidigt konstateras dock att »oro, hot och rädsla är mer centralt för svenskar än tidigare« (Andersson et al. 2018, s 36). Vi vill sätta in resultatet från Novusundersökningen i detta sammanhang och forskarsamhället bör noga följa utvecklingen för en ökande rapporterad oro hos allmänheten inför samhällsutvecklingen. Risken för en ökad oro är att det kan leda till en politik som hittills varit främmande för det som vi lägger i den svenska tillitsmodellen. 
Lars Korsell, Tomas Axelson \& Jonas Stier - Allmänhetens syn på våldsbejakande ...

\section{Referenser}

Agrell, Wilhelm (2019). »Agrell: Vi måste agera för att rädda landet.« Svenska Dagbladet, den 13 september.

Andersson, Ulrika, Carlander, Anders, Lindgren, Elina \& Oskarson, Maria (red.) (2018). Sprickor i fasaden: SOM-undersökningen 2017. [Göteborg]: SOM-institutet.

Axelson, Tomas \& Stier, Jonas (In print). »Religions - A Janus Faced Phenomenon in local politics. A Swedish inter-religious council and participants expectations on religions as a possible asset for social cohesion in the local community«. I Interreligious Studies and Intercultural Theology. Sheffield: Equinox

Axelson, Tomas, Hansson, Ulf \& Sedelius, Thomas (2018). Från privatsak till politisk kraft? Borlänges interreligiösa råd och förväntningar på religion som resurs i lokalsamhället. Falun: Högskolan Dalarna.

Beck, Ulrich (1992). Risk society: towards a new modernity. London: Sage.

Berggren, Henrik \& Trägårdh, Lars (2014). Är svensken människa? Gemenskap och oberoende i det moderna Sverige. Stockholm: Norstedts.

Bjørgo, Tore (2013). Strategies for preventing terrorism. New York: Palgrave Macmillan. https://doi.org/10.1057/9781137355089

Brå (2019). Nationella trygghetsundersökningen 2019. Om utsatthet, otrygghet och förtroende. Brå 2019:11. Stockholm: Brottsförebyggande rådet.

Claesson, Urban (2019). »Lutherska begrepp och nordisk samhällsteologi«. I Ehnberg, Jenny \& Nahnfeldt, Cecilia (red.) Samhällsteologi: forskning i skärningspunkten mellan akademi, samhälle och kyrka. Stockholm: Verbum.

Due Enstad, Johannes och Aasland Ravndal, Jacob (2015). »Hvorfor er det så mye mer høyreekstrem vold i Sverige? « Aftenposten, 3 november.

Eatwell, Roger \& Goodwin, Matthew J. (2018). National populism: the revolt against liberal democracy. London: Pelican.

Eriksson, Johan (2020). Föredrag för Brottsförebyggande rådet den 20 februari 2020.

Fijnaut, Cyrille, Paoli, Letizia och Wouter, Jan (kommande). What is the nexus between organized crime and terrorism? Types, developmental conditions and policies.

Giddens, Anthony (1990). The consequences of modernity. Cambridge: Polity in association with Blackwell.

Korsell, Lars, Axelson, Tomas, Frisk, Liselotte och Stier, Jonas (2020). »Harassment and Threats, Concern and Fear: the Experiences of Local Politicians in Ludvika, Sweden.« Journal for Deradicalization, vol. 22, s. 188-217.

Korsell, Lars (2020). »Sweden: Violent extremism and organised crime«. In: Fijnaut, Cyrille, Paoli, Letizia och Wouter, Jan (ed.). What is the nexus between organized crime and terrorism? Types, developmental conditions and policies.

Lövheim, Mia, Jernsletten, Haakon H., Herbert, David, Lundby, Knut \& Hjarvard, Stig (2018). »Attitudes: Tendencies and Variations«. I Lundby, Knut (red.). Contesting religion: the media dynamics of cultural conflicts in Scandinavia. Berlin: Walter de Gruyter GmbH.

Makarenko, Tamara (2004). »The Crime - Terror Continuum: Tracing the Interplay between Transnational Organised Crime and Terrorism.« Global Crime, vol 6, no 1, s. 129-143. https://doi.org/10.1080/1744057042000297025

Nordiska Ministerrådet (2017). »Tillit - det nordiska guldet« Rapport 2017:731. 
Norris, Pippa \& Inglehart, Ronald (2019). Cultural backlash: Trump, Brexit, and authoritarian populism. Cambridge: Cambridge University Press. https://doi.org/10.1017/9781108595841

Novus (2019). Undersökning av allmänhetens relation till våldsbejakande extremism. Stockholm: Novus 2019-10-28.

Rothstein, Bo \& Holmberg, Sören (2018). »Misstroendets lokalisering i höglitarlandet Sverige«. I Andersson, Ulrika, Carlander, Anders, Lindgren, Elina \& Oskarson, Maria (red.). Sprickor i fasaden: SOM-undersökningen 2017. [Göteborg]: SOM-institutet

Martinsson, Johan \& Andersson, Ulrika (red.). (2019). Svenska trender 1986-2018. Göteborg: SOM-institutet, Göteborgs universitet. https://som.gu.se/digitalAssets/1736/1736224_6.svenska-trender-1986-2018_v2.pdf

Ranstorp, Magnus, Ahlin, Filip, Hyllengren, Peder \& Normark, Magnus (2018). Mellan salafism och salafistisk jihadism: Påverkan mot och utmaningar för det svenska samhället. Stockholm: Försvarshögskolan

SOU 2002:122. Göteborg 2001. Stockholm: Fritzes.

SOU 2016:92. Värna demokratin mot våldsbejakande extremism. Nationell samordning och kommunernas ansvar. Stockholm: Wolters Kluwer.

SOU 2019:49. En ny terroristbrottslag. Stockholm: Norstedts juridik.

Säkerhetspolisen (2010). Våldsbejakande Islamistisk extremism, Stockholm: Swedish Security Service.

Tippe, Frida (2019). Våld och demokrati. SOM-rapport nr 2019:24. Göteborg: Göteborgs universitet.

Trägårdh, Lars (2013). »The historical Incubators of Trust in Sweden: From the Rule of Blood to the Rule of Law«. I: Uggla, Bengt Kristensson, Reuter, Marta \& Wijkström, Filip (red.). Trust and Organizations: Confidence across Borders. Palgrave Macmillan Ltd. https://doi.org/10.1057/9781137368812_10 